\title{
T.В. Савина
}

\section{Новосибирский государственный университет экономики и управления}

\section{Тема бессмертия в «Уединенном» В. Розанова (В.В. Розанов и Ф.Э. Шперк)}

Обложка первого издания «Уединенного» (1912), где был нарисован маленький грустный человечек и могильный крестик на горизонте, могла бы стать иллюстрацией ко всем книгам В. Розанова, написанным в «интимном жанре полухудожественной афористической прозы» [Фатеев, 1995, с. 15]. «Уединенное», «Опавшие листья», «Сахарна», «Мимолетное», «Смертное», даже, в некоторой степени, «Литературные изгнанники» - все это, по сути дела, одна большая книга, в кото рой Василий Розанов просто рассказывал о себе. «Собственно, мы хорошо знаем единственно себя. О всем прочем - догадываемся, спрашиваем. Но если единственная “открывавшаяся действительность” есть “я”, то, очевидно, и рассказывай об “я” (если сумеешь и сможешь)» - писал Розанов в «Опавших листьях» [Розанов, 1990, с. 169]. Несмотря на обилие затронутых тем и упомянутых имен, рассказом «о себе» практически исчерпывается все содержание этих необычных книг.

«Душа моя» - называл свои записи Розанов, и как во всякой человеческой душе, здесь нашлось место всему: вопросы религии и болезнь жены, политика и купленные детям пряники, философия и ворох корректур. С одной стороны - «мелочное», «мимолетное», «паутинки быта», «невидимые движения души», с другой - почти документальное фиксирование мест, дат, имен. И рефреном повторяется один и тот же вопрос: «Один раз, один раз, один раз живет человек на свете... Один раз приходит он на землю. Кто может вынести эту мысль. “Вошел в мир”... И когда “отойду” - никогда больше не вернусь в него. Никогда. Никогда. Ни когда. Кто может это вынести?» [Розанов, 2004, с. 379-380]. Постоянный предмет философской рефлексии, смерть переживалась Розановым как естественный финал земного пути любого человека, но более всего его интересовало, что будет по сле. Причем это «после» мыслилось им не как «Царствие Небесное» и не «загробная жизнь», а как материально-предметный мир, который все равно существует и после его смерти. Этот ужас собственного отсутствия там, где другие продолжают жить, постоянно мучил Розанова: «Вот равнина... поле... ничего нет, никого нет... И этот горбик земли, под которым зарыт человек» [Розанов, 1990a, с. 81]. Именно поэтому Розанов так часто описывал собственное физическое присутствие на своих похоронах: то папироску кому-нибудь из провожающих «подсунет», то колено из савана «выставит» [Там же, с. 82-83]. Розанов, конечно, ерничал, но за всем внешним цинизмом подобных заявлений скрывался не столько страх смерти, сколько страх забвения, страх «прожить жизнь так, как бы ее и не существовало» [Розанов, 1990, с. 127]. Поэтому и смерть других людей, близких или даже незнакомых ему, мучила Розанова не меньше: «Но “человек умер”, и мы даже не знаем - кто: это до того ужасно, слезно, отчаянно, что вся цивилизация в уме точно перевертывается» [Розанов, 1990а, с. 82]. Не столько смерти боялся Розанов, своей или чужой, сколько неизбежного расставания, а спасение от этого страха видел в простой человеческой памяти: «Все мы под старость “поминаем 
покойников”... Что это? Какая таинственная связь? Отчего она так жива и дорога? “Что-то веет оттуда... Откуда? Что веет?” Руками не умеешь схватить, а сердце чувствует... И страшно, и радостно» [Розанов, 2000, с. 221] (курсив автора).

Собственно, многие розановские записи, собранные им в книги, можно было бы назвать «воспоминаниями». Не мемуарного толка, конечно, а как неопределенные «мыслечувства» ${ }^{1}$, приходящие в голову мимолетно, случайно. Наряду со многими великими, известными именами, Розанов с пристальным вниманием вспоминал и «незнаменитых», из числа, что называется, «неудачников», «отвергнутых», «забытых». Среди прочих, особенный интерес вызывает часто упоминаемое Розановым имя молодого критика и философа Федора Эдуардовича Шперка (1872 1897). Практически ни о ком, кроме членов своей семьи, Розанов не писал с такой теплотой, горечью и любовью как о Шперке.

К моменту, когда создавались «Уединенное» и другие книги Розанова (1912 - 1915 гг.), Федор Шперк уже давно умер и всеми был прочно забыт. И если сейчас его имя известно литературоведам, то только как «младшего друга Розанова».

Высказывания Розанова содержат крайне высокую оценку Шперка как критика и мыслителя: «гениальный Шперк», «мальчишка-гений», «проницательный до гениальности», «только одно он давал впечатление: сила, сила идет». Но оказывается, что Розанов был, в общем-то, одинок в своих хвалебных отзывах. Если попытаться найти сведения о Федоре Шперке в мемуарной литературе, относящейся к 1890-м года XIX века, то среди редких упоминаний его имени нет ни одного, сколько-нибудь похвального. Например, среди них можно найти мнение литературоведа и критика П.П. Перцова, который не видел в Шперке ничего, кроме «вдумчивого и осторожного, даже слишком осторожного, критика» [Перцов, 2002, с. 161-162]. После одной из рецензий Шперка, напечатанной в «Новом Времени», П.П. Перцов даже порвал с ним отношения, так же как и критик «Северного Вестника» Аким Волынский. С явной неприязнью писал о Шперке биограф Розанова Э.Ф. Голлербах [Голлербах, 1991, с. 26-27]. Скандальные рецензии, напечатанные Ф. Шперком в «Новом Времени», на книги Вл. Соловьева, А. Волынского, Я. Надсона принесли ему репутацию «наглого» и «самоуверенного» критика. Сам же Розанов при жизни Шперка, т.е. в 1890-х годах, ни разу в своих публичных оценках не поднялся выше просто доброжелательной рецензии.

В личных отношениях и переписке Розанов также не был щедр на комплименты, скорее напротив. Время от времени он напоминал Шперку «о необходимой скромности» с его стороны, о своем энтузиазме по отношению к Шперку, «который может выдохнуться» [Письма, Л. 38]. Шперк постоянно обращался к Розанову с просьбами свести его с нужными людьми: издателями, журналистами, литераторами. При этом очень часто письма Шперка звучали не в том тоне, которого требовали отношения уже известного литератора и начинающего критика. Более того, одна из настойчивых просьб Шперка (вторично написать рекомендательное письмо к А.А. Александрову, главному редактору «Русского Обозрения») повлекла за собой ссору. Шперк ответил Розанову резким письмом, объявив дальнейшее знакомство невозможным: «К Вам я не приду, пока Вы не отрезвитесь. Надо же, помимо любви к человеку, иметь к нему хоть каплю уважения» [Там же, Л. 42].

В литературных полемиках тех лет Розанов нередко выступал против Шперка, как, например, в дискуссии о книге Вл. Соловьева «Оправдание добра» и в полемике вокруг книги А. Волынского «Русские критики». Репутацию «наглого» и «самоуверенного» критика подкрепляли крайние и несправедливые оценки, которые направо и налево раздавал Шперк. «Бросьте Вашего патологически-доброго Леонтьева» - писал он в одном из писем Розанову. В его письмах

1 Этот термин обширно используется в розановедении, например, в работах Г.Д. Гачева, В.А. Фатеева и др. 
можно найти «тупого немца» Гегеля, «банального и циничного» Достоевского, «изящные грубости» Тургенева. И совсем не церемонился Шперк с современными ему литераторами. В его литературно-критических статьях появляются «иезуитизм в философских одеждах» Вл. Соловьева, «тщеславный и мелочный» Я. Колубовский, «мнимо-философское фиглярство» Н. Минского, приписываемые А. Волынскому требования «с ножом к горлу» ко «всем русским критикам перемены русского паспорта на еврейский» [Шперк, 2001, с. 26, 31, 92].

Таким образом, реальная фигура Федора Шперка не совсем соотносится с тем образом, который возникает на страницах «Уединенного» и «Опавших листьев». Но речь здесь может идти не о том, что Розанов заблуждался относительно ума и дарования Шперка. Скорее можно говорить о том, что спустя полтора десятилетия после смерти «младшего друга», он в своих книгах создал сквозной образ, персонаж единого художественного текста, в котором Шперк существует как некий знак, обозначающий своим присутствием звучание определенной «розановской» темы: смерть и бессмертие. Для Розанова Шперк важен и значителен прежде всего именно тем, что практически «не был», ни в чем не состоялся: литературный неуспех, короткая жизнь, стремительное забвение. Розанов не упоминает ни одной статьи Шперка, не дает никаких оценок, кроме «проницательный» и «гениальный», что в контексте, например, «Уединенного», оценкой считать нельзя. Да и тот факт, что Шперк был философом и литературным критиком, не имеет для Розанова особенного значения: образ Шперка оказался несущей конструкцией мощного потока рефлексии на тему бессмертия: «Сказать, что Шперка теперь совсем нет на свете - невозможно. <.. > И не то, чтобы “душа" Шперка - бессмертна: а его бороденка рыжая не могла умереть. “Бызов” его (такой приятель был) дожидается у ворот, и сам он на конке направляется ко мне на Павловскую. Все как было. А “душа” его “бессмертна” ли: и - не знаю, и - не ин тересуюсь» [Розанов, 1990а, с. 93]. Бессмертие Шперка состоит для Розанова в том, чтобы запомнить и потом воссоздать «все как было».

В судьбе Шперка Розанов угадывал некоторым образом свою собственную возможную судьбу. «Не симпатичный, угрюмый учитель (гимназии), написавший огромную книгу («О понимании»), немного сумасшедший» [Розанов, 2004a, c. 144] - это высказывание о молодом Розанове середины 1880-х годов перекликается с отзывами о Шперке: «чудак, непонятный философ» [Перцов, 2002, c. 262], «как его осмеивали и гнали при жизни! Неужели надо умереть, чтобы добиться серьезного отношения?» [Брюсов, 1927, с. 31]. Также можно заметить практически текстуальные совпадения в оценке ранних философских работ Розанова: «Нашелся какой-то г. Розанов, который написал несколько безнадежноплоских пошлостей» [Без подписи, 1895, с. 60-61] и Шперка: «Он издал ряд маленьких брошюр на философские темы, представляющих собою перепевы кое-каких мотивов классической философии» [Голлербах, 1991, с. 19]. Отсюда горечь Розанова, вызванная не только ранней смертью Шперка, но и его забвением. «Сравнительно с "Рцы” и Шперком как обширно развернулась моя литературная деятельность, сколько уже издано книг», - чуть ли не с удивлением отмечает Розанов. «Но какова судьба литературы: отчего же они так не знамениты, отвергнуты, забыты?» [Розанов, 1990а, с. 71]. При этом акцент делается не на том, что он «знаменит» («"Известность” иногда радовала меня, - чисто поросячьим удовольствием. Но всегда это бывало недолго») [Там же, с. 50], а на том, что они - «забыты».

Шперк практически лишен реальной биографии, но закономерно то, что Розанов описывает Шперка, подчеркивая те обстоятельства его личной жизни, которые были важны и значимы для него самого, как, например, жизнь в семье. Опи санию семейного счастья Шперка Розанов посвящает большую запись в «Опавших листьях» [Розанов, 1990, с. 365-366] и целую страницу в «Литературных из- 
гнанниках» [Розанов, 2000, с. 245]. Интересно, что воспоминания Розанова о том, «как Шперк любил свою Анну Лавровну» предваряются пассажем о двух «немцах, с большим положением, женатых на русских». Однако то, что Шперк по матери был евреем, а по отцу имел шведско-норвежские корни, совершенно для Розанова не важно. На этот счет у него есть только одна оговорка - «человек не русского покроя» [Розанов, 1897], сделанная в некрологе на смерть Шперка и спустя пятнадцать лет совершенно потерявшая значение.

Реальные факты биографии Шперка под рукой Розанова превратились в определенные элементы, составляющие личность собственно самого Розанова в перспективе 90-х годов XIX века: философ-самоучка как представитель «неофициальной ветви» русской философии; литератор, не приемлющий устоявшихся оценок и шаблона; постоянная рефлексия даже в бытовых мелочах; мыслитель, ищущий новых путей самовыражения.

Практически все, что цитирует Розанов, представляет собой суждения Шперка о нем как о личности или оценку тех или иных его работ: Шперк не любил книгу «О понимании» и ему нравилась статья «Красота в природе и ее смысл» [Розанов, 2000, с. 93, 102], Шперк любил самого Розанова, но как в человеке находил в нем «что-то мутное в организации или крови», какую-то нечистую примесь [Розанов, 1990а, с. 57]. Причем все его высказывания принимаются на веру: «И если это сказал, значит, это верно». В результате Розанов в книгах, в ко торых ведущими являются субъективные впечатления и мысли, добивается ощущения определенной объективности в оценке самого себя - не «Розанов о Розано ве», а некий взгляд со стороны, независимое суждение Шперка (причем временная дистанция в пятнадцать лет придает этому суждению устойчивость).

О тех фактах, которые противоречили создаваемому образу, Розанов просто не упоминает. Кроме чисто биографических данных, Розанов также мифологизирует или опускает определенные моменты творческой биографии Шперка. Например, Шперк никак не мог говорить о себе: «Я, батенька, декадент». Он постоянно выступал против «декадентов», со страстью отстаивая принципы классической литературы. Рецензии Шперка на книгу А. Волынского «Русские критики», а также на его же статьи о Лескове, помещенные в «Северном Вестнике», были направлены преимущественно против метода «декадентской» критики [Шперк, 2001, с. 92]. С другой стороны, Шперк с симпатией принял художественное новаторство Ф. Сологуба, приветствуя его общую психологическую направленность [Там же,с. 21]. И, если вспомнить о неосознанных проявлениях «декадентского мироощущения» у самого Розанова, то эта запись выглядит достаточно убедительной. Более того, по наблюдению В.А. Фатеева, «ряд действительно проницательных обобщений критика (Ф.Э. Шперка - Т.С.) о сути декадентства поразительно подходит для характеристики... Розанова более позднего периода» [Фатеев, 2002, с. 188], т.е. 1900-х годов (примечателен в этом отношении пассаж Розанова о «психопатах» и «декадентах» [Розанов, 1990а, с. 43]).

Вместе с тем, другая сторона этого процесса - «Шперк глазами Розанова» получила в его записях иное развитие. Розанов, спустя полтора десятилетия после смерти Федора Шперка, не интересовался ни подробностями литературных полемик, ни деталями его жизнеописания. Совершенно не важным оказалось, был ли Шперк литератором или, скажем, врачом или инженером. В отношении Шперка как просто человека, слишком рано ушедшего, самым главным было стремление воссоздать просто жизнь, которая «в миниатюрных и будничных чертах не беднее, в сущности, и вовсе не хуже самого высокого творчества» [Розанов, 1990б, c. 229]. Розанов буквально «воскресил» Шперка, наполнив текст подробным описанием его внешности («бороденка рыжая», «дырочка в сапоге»), вспомнив имя его жены (Анна Лавровна) и фамилию друга (Бызов), которого никогда в жизни не видел [Розанов, 1990, с. 136, 365], брата Шперка, сырую квартиру, в которой 
тот жил, и квартирного хозяина [Розанов, 2000, с. 245]. Все эти мелочи, несущественные для официальной биографии, в своей совокупности воссоздали абсолютно реального и живого человека. «Синтез мысли, факта и образа», на котором основывается созданный Розановым жанр «уединенного» [Фатеев, 1995, с. 15], определил основной механизм создания образа Федора Шперка.

«Если бы не Розанов, ...то сейчас бы о Шперке никто бы и не вспомнил» пишет исследователь жизни и творчества Розанова В.А. Фатеев. Может быть, это и так. Тем не менее, Розанов сумел не только себя, но и Шперка, хотя бы в качестве своего «младшего друга», защитить от небытия.

\section{Литература}

Без подписи. Рецензия на кн. Ипполит Тэн. Об уме и познании (2-е изд. Пер. Н.Н. Страхова) // Русское богатство. 1895. № 3.

Брюсов В.Я. Дневники. М., 1927.

Голлербах Э.В. В. Розанов. Жизнь и творчество. М., 1991.

Перцов П.П. Литературные воспоминания. 1890-1902. М., 2002.

Письма Ф.Э. Шперка к В.В. Розанову. РГАЛИ, ф. 419, оп. 1, ед. хр. 709.

Розанов В.В. Ф.Э. Шперк // Исторический Вестник. 1897. № 12.

Розанов В.В. Опавшие листья // Розанов В.В. Уединенное. М., 1990.

Розанов В.В. Уединенное // Розанов В.В. Уединенное. М., 1990а.

Розанов В.В. Сочинения. М. 1990 .

Розанов В.В. Литературные изгнанники. Воспоминания. Письма. М., 2000.

Розанов В.В. Мимолетное. 1914 год // Розанов В.В. Миниатюры. М., 2004.

Розанов В.В. Смертное. М., 2004а.

Фатеев В.А. Публицист с душой метафизика и мистика // В.В. Розанов: pro et contra. Личность и творчество Василия Розанова в оценке русских мыслителей и исследователей. Антология. Спб., 1995. Книга I.

Фатеев В. Жизнеописание Василия Розанова. С русской бездной в душе. СПб.; Кострома. 2002.

Шперк Ф.Э. Литературная критика. Новосибирск, 2001. 